\title{
Thrombin Alfa
}

National Cancer Institute

\section{Source}

National Cancer Institute. Thrombin Alfa. NCI Thesaurus. Code C29499.

A recombinant peptide that is chemically identical to or similar to the endogenous

thrombin. Thrombin, a serine protease, plays significant roles in the coagulation cascade,

such as breaking down soluble fibrinogen to promote fibrin clot formation, as well as activating factor XI, factor $\mathrm{V}$, and factor VIII. 